\title{
Two Dogs Fight and a Third Grabs the Bone. Reasons for the Electoral Success of Unexpected Candidates - the Croatian Political Scene after the Last Two Parliamentary Election Cycles (2015-2016) ${ }^{1}$
}

\author{
Dominika Mikucka-Wójtowicz ${ }^{2}$
}

\begin{abstract}
The last two years in Croatian politics can be seen as an important turning point. The most recent two parliamentary election cycles (2015-2016), as well as the presidential race held a year earlier, were both more interesting and more unpredictable than the previous elections. The objective of this article is to analyse and identify their distinguishing features as well as their significance and implications for the further functioning of the Croatian political scene. Owing to the fact that in both electoral cycles an important voice in the shape of the ruling coalition went to the party that came third in the election and, also surprisingly, this was both a newly established formation and to a great extent with an antiestablishment appeal, particular attention is focused on the appearance on the party scene of new political groupings. The article attempts to place them within the framework of the existing new party typologies and point to the main reasons for their electoral success, as well as evaluating their chances for survival on the party scene.
\end{abstract}

Key words: Croatia, parliamentary elections, government formation, new political parties, party survival

\section{INTRODUCTION}

The Croatian party system was reasonably fast to consolidate, compared to the region's other states, despite the relatively low costs of entry of new parties onto the election market, measured by both the ease of their registration and their genuine prospects for gaining parliamentary seats (Tavits, 2007, 115). ${ }^{3}$ However,

\footnotetext{
1 The article was written as part of research project no. UMO-2015/16/S/HS5/00093, "Europeanisation of parties and party systems in post-Yugoslav states against the background of the experiences of Central and Eastern European countries - similarities, perspectives, challenges", financed by the National Science Centre in Poland.

${ }^{2}$ Dr. Dominika Mikucka-Wójtowicz, Faculty of Political Science and International Studies, Institute of European Studies, University of Warsaw, Poland, Nowy Świat 69, 4th floor, 00-927 Warsaw, e-mail: domiwojt@gazeta.pl; d.mikucka-wojt@uw.edu.pl.

${ }^{3}$ In order to register a party, it is necessary to organise a founding convention and collect 100 signatures of support. The electoral threshold is counted separately for every district. This has its drawbacks, as it does not favour groupings whose support is concentrated geographically.
} 
such parties have seldom gained parliamentary seats, and when they have, the numbers have been small. Since 2000 and the so-called watershed elections, when the decade-long domination of the Croatian Democratic Union (HDZ) came to an end, only three newly formed groupings have managed to win seats: the Croatian Pensioners Party (HSU), a so-called one-issue party, the regional rightwing Croatian Democratic Alliance of Slavonia and Baranja (HDSSB), and the leftist Croatian Labourists (HL). In addition, several parties have secured (modest) parliamentary representation as a result of party splits during the term of office, as opposed to the run-up to elections (Nikić Čakar and Čular, 2016, p. 110). As the Croatian political scientist Mirjana Kasapović rightly notes, the reason for this was that the votes made for new parties generally crumbled away, and they were ultimately unable to exceed the threshold (Kasapović, 2016), which led to an increased percentage of unrepresented voters, in 2011 reaching a level of $18.5 \%$. This meant that almost $20 \%$ of voters were not represented in parliament. A further worrying sign related to this was the declining voter turnout, and, as Allan Sikk notes, one can hardly speak of stability when voters are forced to confront the "unhealthy closedness of the political scene where the only real option for dissatisfied voters is to exit from the electoral game" (Sikk, 2005, p. 409).

The last two years in Croatian domestic politics have been extremely tempestuous and laden with unexpected events. During this period, Croatians have gone to the polls on three occasions, once to elect the head of state, and twice parliament. Each of these elections contrasted markedly with the previous electoral cycles. In the presidential elections, for the first time in history the candidate seeking re-election lost the electoral race, despite leading in the polls until the last moment. In the parliamentary elections of November 2015, third place was taken by Most, a newly formed loose coalition created by local politicians, whose electoral success gave it such potential for coalition (but also blackmail) that it tipped the scales in the negotiations on forming the future government. For some time it was unclear whether it was with the SDP or the HDZ that Most would form a coalition, but ultimately the latter option was chosen. The new cabinet was headed by a virtual unknown in the country, Tihomir Orešković, a Croatian Canadian financial manager working for the Teva pharmaceutical company. From the outset his cabinet was saddled with the mutual distrust of its constituent parties, resulting in internal tensions. The next novelty was the fact that the government collapsed after less than half a year following a motion of no confidence in the prime minister initiated by the then HDZ leader. A further surprise was the fact that, despite internal tensions within the coalition, after the early parliamentary elections held in September 2016 the new government was formed by the same parties. 
The objective of this article is to analyse the elections held in Croatia in 20152016 and identify their distinguishing features as well as their significance and implications for the further functioning of the Croatian political scene. Particular attention is focused on the appearance on the party scene of new players and an attempt to place them within the framework of the existing new party typologies, pointing to the main reasons for their electoral success, viewed not only from the perspective of domestic politics but also in the wider European context, and assessing their chances for survival on the party scene.

\section{HOW MUCH NOVELTY IN NEW PARTIES?}

The arrival, and especially successes, of newly formed parties on the electoral scene provokes much discussion among social researchers. Even the very term "new parties" is a controversial one. As Robert Harmel and John D. Robertson stated, "new parties are formed primarily to fill representational needs of the society" (Harmel and Robertson, 1985, p. 502). According to Ferdinand MüllerRommel, the reason for this is that "old parties have failed to absorb new issues into their agendas and programmes" (cited in: Sikk, 2011, p. 466). A number of authors, however, argue that new groupings do not necessarily have to focus on promoting new issues, but also may enter the political landscape on the territory occupied by established parties and even "not differ much from old parties regarding their policy positions" (Sikk, 2011, p. 468, 480). What's more, very often, "embracing new issues can be difficult, because of legacies, party images, leaders' and voters' preferences" (Sikk, 2011, p. 481).

Another criterion for distinguishing new groupings was proposed by Thomas Poguntke, for whom the question of newness should rather refer to the type of party organisation (cf. cf. Beyens, Lucardie and Deschouwer, 2015, p. 259). This is important because, as Sikk rightly notes, "not all parties that seem new are new" (Sikk, 2007, p. 397). For example - as is particularly often the case in Central and Eastern European states - new parties can emerge as a result of splits within other parties, or alternatively several groupings can join together, or parties can simply change their name. Furthermore, "technically new parties" can be founded by people who previously functioned in a non-party capacity; this usually applies to previous heads of government or ministers (Sikk, 2007, p. 397). It is therefore hardly surprising that Margit Tavits, for example, employs the term "genuinely new parties"; such a party is only one that "emerges without any help from members of existing parties" (Tavits, 2007, p. 115). Shlomit Barnea and Gideon Rahat, on the other hand, argue that parties can be both new and old at the same time, depending on which dimensions of their operation (label, 
platform, electorate or organisation) we are considering (cf. Beyens, Lucardie and Deschouwer, 2015, p. 259).

What these authors do agree upon is that the number of new players is markedly higher in countries with proportional voting systems, which result in reduction of the costs of entering the electoral market as well as increased opportunities for both gaining sufficient support for securing seats in parliament and achieving the "benefits of office" (Tavits, 2006, p. 102-106; 2007, p. 115117; Largo and Martinez 2011, p. 5).

But it is important to remember that, although in theory the emergence of new formations can lead to greater diversity of electoral choice, this phenomenon also has negative consequences. As Margit Tavits notes, "The frequent emergence of new parties and their electoral success hinder the development of stable links between parties and voters", which both prevent "developing party loyalties and $[\ldots]$ undermine party institutionalization" (Tavits, 2007, p. 113). This is particularly visible in the so-called young democracies of Central and Eastern Europe, where on average five or six new parties, altogether gaining 19\% of votes, are formed in each electoral cycle after a change of regime. Some very new parties have even been part of governments. By way of comparison, in Western Europe between 1945 and 1991 on average there was only one new formation for every election, securing just $2 \%$ of votes (Tavits, 2007, p. 114). Although, as we shall see later on, the costs of entry of new parties onto the election market were rather low, to date the Croatian party system has been closer to Western than Central European democracies.

\section{THE PARLIAMENTARY LEGISLATIVE ELECTORAL SYSTEM}

In elections to the Sabor, a proportional voting system applies, with the term of office lasting four years. All adult citizens have active voting rights. According to the Constitution, the parliament, which since 2001 has a single legislative chamber, can consist of between 100 and 160 deputies (Article no. 72 , The Constitution), chosen in 12 electoral districts, two of which have a special status. The country was divided into 10 districts, each of them electing 14 deputies. The regulations dictate that differences in the size of these districts (the number of eligible voters ${ }^{4}$ ) should be no more than $+/-5 \%$, but in practice half of them have greater differences, in extreme cases even two or three times bigger (the largest disproportions occur in electoral district IX, which encompasses the Lika-Senj, Zadar, and Šibenik-Knin counties and the northern part of the Split-Dalmatian county). To gain seats, parties must exceed the 5\% electoral ${ }^{4}$ In the 1990s there was a debate over whether the size of a district should be measured by the number of residents or number of voters (people entitled to vote). 
threshold, counted separately for each district, while the d'Hondt method is used to distribute seats. In the first of the two additional districts, Croatian emigrants (the diaspora) choose their representatives. Since 2010, they have had a fixed number of seats - three. ${ }^{5}$ This group of voters is often described as a fictitious electorate, as the vast majority have dual citizenship of Croatia and Bosnia and Herzegovina (Kasapović, 2001, p. 28; Zakošek 2002, p. 26-27), and far fewer votes are required to gain a seat than in Croatia. In the most recent elections, just 2040 votes were sufficient - this was the result of Ivan Šuker (former HDZ finance minister). The three HDZ deputies who entered parliament from the diaspora list achieved a total of 12,350 votes. The 12th and last electoral district is reserved for the representatives of national minorities, who elect eight deputies. Three of these seats go to the representatives of the Serbian minority, and the other five to the remaining minorities, a detailed list of which is contained in the electoral law (Article no. 17, Zakon o izborima). The elections in this district employ a majority system. NGOs have highlighted the fact that they infringe the principle of secrecy, as voters have to declare to the commission if they want to vote for party lists registered in a given district or for a special list of minority representatives, which can lead to stigmatisation. On the other hand, for specialists in electoral law controversial is the very fact that places are reserved on a top-down basis for representatives of minorities, as the number of votes needed for a seat is incomparably lower than in voting for electoral lists. ${ }^{6}$ A recurring idea is that minority voters should have two votes: for party lists and for minority candidates, with the latter having reduced powers in comparison to other deputies. ${ }^{7}$

Until the changes in the electoral law in June 2015, voting took place for closed party lists. According to the new regulations, voters can identify their preferences within lists. However, for candidates to be given these preferential votes, they need at least $10 \%$ of the votes made to their list (Article no. 40, Zakon o izborima). During the discussions on potential further changes to the law, specialists from the GONG think-tank that monitored the elections proposed the introduction of solutions reducing the disproportions between the votes given to parties and the seats they gained. In 2011, the victorious Kukuriku coalition gained $16 \%$ more seats than its percentage of votes ( $40.72 \%$ votes, $57 \%$ seats). ${ }^{5}$ The number previously depended on the average number of votes required to secure a seat in the country.

${ }^{6}$ In 2015, the smallest number of votes needed to win a seat was that of the representative of the Albanian, Bosnian, Montenegrin, Macedonian and Slovenian minorities. It went to Ermina Lekaj Prljaskaj, with just 999 votes.

${ }^{7}$ Implementation of such solutions was foreseen in the 2002 constitutional law on protection of minority rights, while such a possibility was also included in the amended constitution of 2010 , but not introduced to the legislation. 
The equivalent difference for their main rival, the HDZ, was $9 \%$ (23.93\% votes, $33 \%$ seats). By way of comparison, the think-tank analysts showed that in Germany the figure is between 4 and $7 \%$ (GONG 2014: 8).

Although recent years have brought no changes in the formal conditions of competition affecting the cost of new groupings gaining seats in parliament, the 2015 election campaign made the weakened position of the two largest parties clear, along with the increased significance of new players. This indicated the possibility of changing both the format and the mechanisms of the party system. In fact, such potential changes had already been heralded by the presidential elections, in which the leader of the new Human Shield (Živi zid) group surprisingly claimed third place.

\section{ELECTORAL CAMPAIGN - THE ARRIVAL OF NEWCOMERS}

Josipovic's defeat in the presidential race was a bitter pill to swallow, especially as a major factor in Grabar-Kitarović's victory was the voters of the so-called diaspora, mostly dual-citizen residents of neighbouring Bosnia and Herzegovina. Without their support, the HDZ candidate's advantage amounted to just 1989 votes. Liberal commentators on political life were quick to argue that this situation demonstrated the need for debate on the voting rights of Croatian emigrants, since the fact that their votes determined the shape of the domestic political scene meant Croatia becoming a state with limited sovereignty (Lovrić, 2015). The HDZ were bolstered by their win - their fourth in a row since Tomislav Karamarko had become leader (following two rounds of European Parliament elections and local government elections) - and given renewed optimism for the parliamentary election due in autumn 2015. Yet these successes lulled them into a false sense of security, and the relative success of joining the coalition government that long and tempestuous negotiations ultimately brought proved to be hard-earned.

On 28 September 2015, by a majority of the 123 deputies present at the sitting, the Sabor voted for self-dissolution. After consultations with the parliamentary parties, President Grabar-Kitarović set the date of parliamentary elections for 8 November. A total of 166 lists were registered (161 from parties), with the largest number - some 20 - being in electoral district I, which includes Zagreb. There were 2311 candidates for seats in parliament, 957 of them women (41.4\%). As in the previous election cycle, the main rivals were the SDP and HDZ, which headed broad coalitions. Joining the SDP in the Croatia is Growing (Hrvatska raste) coalition were the Croatian People's Party - Liberal Democrats (Hrvatska narodna stranka - Liberalni demokrati; HNS), Croatian Party of Pensioners 
(Hrvatska stranka umirovljenika; HSU), Croatian Labourists - Labour Party (Hrvatski laburisti - stranka rada), Authentic Croatian Peasant Party (Autohtona hrvatska seljačka stranka; AHSS), and Zagorje Party (Zagorska stranka; ZS). This time, the centre-left camp was missing the Istrian Democratic Assembly (Istarski demokratski sabor, IDS), which was leading a small coalition of Istrian regional parties. The HDZ's coalition partners were the Croatian Peasant Party (Hrvatska seljačka stranka, HSS), Croatian Party of Rights Ante Starčević (Hrvatska stranka prava dr Ante Starčevi, HSP AS), Bloc Pensioners Together (Blok umirovljenici zajedno, BUZ), Croatian Social Liberal Party (Hrvatska socijalno liberalna stranka, HSLS), Oak - Movement for Successful Croatia (HRAST pokret za uspješnu Hrvatsku, Croatian Christian Democratic Party (Hrvatska demokršćanska stranka, HDS), and Zagorje Democratic Party (Zagorska demokratska stranka, ZDS). The monthly Cro-Demoskop polls of support for political parties, conducted by the Promocija Plus agency, demonstrated a clear lead - up to $6 \%$ - for the HDZ, until the summer holiday, yet this then fell to just $0.2 \%$. Furthermore, although the pre-election polls gave a visible advantage to both coalitions, each with between 25 and $30 \%$ of votes, from the outset it seemed unlikely that either would be able to form a government on its own.

Polls showed that several parties were vying for third spot (Graph 1). The main ones were the ideologically vague Human Shield, whose leader had unexpectedly secured a surprisingly good result in the presidential elections and gained over $16 \%$ of the votes, as well as the ecological, left-wing party $\mathrm{ORaH}$, founded by former SDP activist Mirela Holy, who in the 2014 European Parliament elections had gained $9.4 \%$ of votes, giving her third place and taking a seat away from the Croatian Labourists. In early 2015, both parties retained close to $10 \%$ support, but before the elections this sank to the extent that they were far from certain of reaching the election threshold. Again somewhat surprisingly, their place in the polls was taken by Bridge of Independent Lists (Most), a grouping comprising local activists from various regions.

Analysing the situation of the parties that have managed to exceed the election threshold in the last five years in Croatia suggests that both groups of the aforementioned scholars are right. This means that we can find among Croatian newcomers parties that try to put new issues into their agendas (or to represent thus far neglected groups of voters), but also groupings established by dissidents from other parties which believe that their parent formation has lost sight of the issues and are keen to refocus it. According to the typology of new parties, formations such as the Croatian Labourists and ORaH might be called "challengers", to use Thomas Rochon's term, or "purifiers", according to Paul Lucardie, as they were founded by "dissident members of an established party 
which revised its traditional ideology" (Lucardie, 2000, p. 177). In the first case, these came from the HNS, and promised a return to the party's original social economic programme. In the second, they emerged from the SDP, and attempt to find the typical values of the modern left by emphasising the importance of environmental policy - as reflected, incidentally, in the party's full name Sustainable Development of Croatia.

Yet these parties soon found their electoral fortune dissipating. Having shone in one (ORaH), or at the most two (Labourists) election cycles, they later disappeared from the party scene. The situation is more complicated with the next two groupings: Human Shield and Most. Referring to Human Shield, according to the typology of new parties created by Lucardie and modified by Allan Sikk, we could classify it as a "prolocutor"-type party, "not linked to ideologies but aim[ing] to represent a particular issue or an interest in a society" (Sikk, 2011, p. 466) and founded by a group of young activists without previous political experience seeking to represent a "neglected group" (Lucardie, 2000, p. 176). In this case this meant people threatened with eviction, and later also struggling to pay off mortgages taken out in Swiss francs. It is hard to evaluate Human Shield's long-term prospects, although, as Lucardie underlines, with parties of this type it is likely to disappear as quickly as it emerged when the issues that it highlights become part of the political agenda (Lucardie, 2000, p. 176). Also problematic is the fact that the party does not attach importance to creating organisational structures, which, as studies on new parties' survival chances show, significantly weakens their prospects. This is because the weakness of the party organisation means that it is harder for parties to survive the shock caused by electoral defeat or party splits (Beyens, Lucardie and Deschouwer, 2016, p. 270). 
Graph 1: Declared support towards the main political parties and coalitions in the parliamentary elections 2015-2016

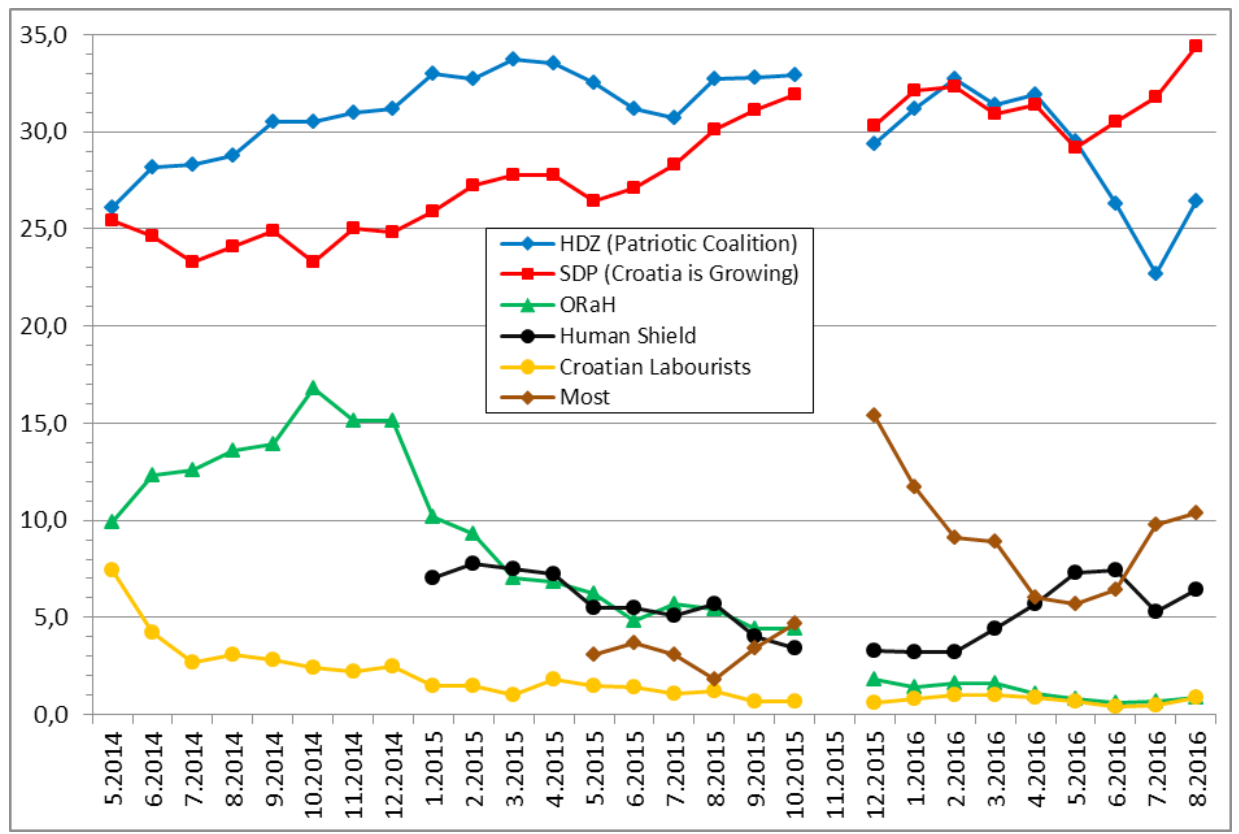

Source: author's own elaboration based on the data of CRO Demoskop surveys published by the agency Promocija Plus, http://www.promocija-plus.com/javno_mnijenje/index javno_mnijenje.htm (November 20, 2016). Note: surveys are not conducted in electoral months.

The most interesting example of a newly established party is undoubtedly Most, whose activists, observing their increased popularity in the pre-electoral polls in 2015, began to stress that their objective was to tip the balance during the future coalition talks (Hudelist, 2015, p. 19). In formal terms, at the time of its first electoral success Most was not a party, as it eschewed typical party structures. The situation changed markedly only in January 2017, when Most organised a party convention and started to build its organisation. Up till then it was rather a loose coalition of local politicians. However, especially its leadership treats the term "coalition" as prohibited. Its de facto leader is Božo Petrov, mayor of the town of Metković in the Dubrovnik-Neretva County. In the 2013 local elections he was successful in defeating Stipe Gabrić Jambo (initially associated with the HDZ, and later the HSS), who had governed the town for 16 years despite frequent accusations of corruption and economic crimes. Yet several 
other activists played an important group in Most during the campaign. They included its economic strategist, the former dean of the Faculty of Economics of the University of Zagreb Ivan Lovrinović; Mayor of Primošten Stipe Petrina, a bitter opponent of HDZ policy (in 2013 Petrina famously renamed the city centre street named after Franjo Tuđman, whose thieving privatisation in the 1990s he blamed for the impoverishment of the Croatian nation); and Drago Prgomet, a former long-time HDZ activist and its deputy leader from 2012, who left the party in 2015 after a conflict with its leader Tomislav Karamarko (Tagirov, 2015).

Therefore, owing to the presence of experienced politicians in its ranks, Most cannot be called "genuinely new", which in any case is regarded as very problematic term (Tavits, 2007, p. 123). ${ }^{8}$ Classifying it also causes certain problems. Firstly, it is clear that the grouping founded its strength (rather unexpectedly) on the disappointment of the voters of the two main parties, as well as the fact that they did not see an alternative among the existing parties. If we look at Most's ideological profile we can observe a dizzying mixture of various, often not matching elements as well as a certain political illiteracy, an example of which is the attempt to expunge the term "coalition" from the political discourse. What really set Most apart from other options, however, was simply the power of their novelty, based on their "wish to change the manner of doing politics rather than the contents" (Sikk, 2011, p. 467).

Other groupings competing for votes included the right-wing regional Croatian Democratic Alliance of Slavonia and Baranja (Hrvatski demokratski savez Slavonije i Baranije, HDSSB) and the People's Party - Reformists (Narodna stranka - Refrmisti, NRS) of the former deputy prime minister, minister of economy and HNS leader Radimir Čacić, which headed the Successful Croatia (Uspješna Hrvatska) coalition. In Zagreb, former president Ivo Josipović, leader of the newly formed Go Ahead Croatia-Progressive Alliance (Naprijed Hrvatska) figured on this coalition's list, and in Rijeka the former minister of finance in the Kukuriku coalition government Slavko Linić, expelled from the party in June 2014 following a conflict with Zoran Milanović. A separate list was registered by Milan Bandić, also a former SDP politician and long-time mayor of Zagreb.

Once again, economic issues were among the main themes of the election campaign, following six years of recession. The Kukuriku coalition government claimed that the Croatian economy had passed the worst period, with its politicians speaking about the benefits from the inflow of European Union funds (in practice, though, their exploitation was limited, at only 52\%) and GDP growth,

\footnotetext{
${ }^{8}$ One gets the impression, incidentally, that activists forming new parties often emphasise their previous experience, counting upon this to pay dividends among voters. For example, the members of another new grouping, the People's Party - Reformists Party, refer to themselves as a new party of old HNS personnel.
} 
whose rate was $1,2 \%$ in August. Before the campaign officially got underway in September, Finance Minister Boris Lalovac decided to convert mortgage taken out in Swiss francs into euro, which, thanks to the rigid exchange rate between the kuna and the euro was supposed to eliminate the currency risk and help those with the greatest debts. Opposition politicians criticised the government's actions, however, deeming them insufficient. The HDZ presented solutions to solve problems in the special economic programme, which was drawn up in cooperation with the Ifo Institute for Economic Research (closely associated with the German CDU, a sister party of the Croatian Christian Democrats). Thus, it can be perceived as an example of the Transnational Party Cooperation's (TPC) influence (Mikucka-Wójtowicz, 2016). They announced that party's main goal is to launch new employment, as well as encouragement of entrepreneurs and start-ups through special sources of financing. In turn, Most's economic programme included promises of an expansive monetary policy, working with trade unions, and increased investment in the energy sector and irrigation systems. The grouping's head economic strategist accused the two main parties of having set up and abetted a crony capitalism in the country that had led to the development of permanent links between large business and the representatives of the political elite (Lovrinović, 2015, p. 13). One of Most's major proposals was state decentralisation, including reduction in the number of districts and counties. Despite the domination of economic issues, the campaign was also not short of accusations levelled between the main rivals. The SDP warned of the "Orbanisation" of Croatia in the event of an HDZ win, and the HDZ countered by calling the governing coalition "Yugophile" and unpatriotic. The SDP election strategy, however, displayed a distinct "patriotic turn", which could be seen during the party's first pre-election rally, as they opened up to direct contacts with voters (Večernji list, 2015; Jutarnji list, 2016). In spite of the escalation of the migrant crisis during the campaign (between 300,000 and 600,000 people passed through the post-Yugoslavian states in the second half of 2015), this problem, like other issues connected with further integration (e.g. implementation of the euro) and the functioning of the EU were not an important topic in the speeches of the rival parties. This is hardly surprising, as interest in integration issues tends to drop after accession. Although the main parties generally avoided difficult subjects in the election campaign, this gave the impression that they were not flexible enough and had no plan for dealing with the accumulation of challenges. 


\section{RESULTS - HOW TO PREDICT THE UNPREDICTABLE}

The election, which took place on 8 November 2015, boasted a turnout of $60,8 \%, 6,5 \%$ more than in 2011. The unexpected outcome and strong results achieved by Most led not only to coalition negotiations lasting some 75 days, with many unexpected twists and turns and a post-election stalemate, but also to an extensive reshaping of the party scene. To a greater extent than the previous one, then, this election can be described as a critical election (Key, 1995, p. 3-4; Kasapović, 2011). The results were surprising as none of the parties secured an outright majority. The Croatia is Growing coalition gained $33.2 \%$ of the vote, and their main rivals the Patriotic Coalition 33.4\%, giving each of them 56 seats (Table 1). Importantly, the patriotic bloc were also strengthened by the three representatives of the diaspora, while the IDS promised to support the centreleft coalition. Mindful of the debate on removing the diaspora's voting rights that had followed the previous year's presidential election, when a major role in the HDZ candidate's victory had been played by the vote from neighbouring Bosnia and Herzegovina, the president opted not to ask the HDZ leader to form a government, despite the election-night congratulations offered to the party. The biggest surprise was the result secured by Most, despite pre-election polls showing growing support for the list. With $13.5 \%$ of votes, the grouping gained 19 seats, thus realising its leaders' dreams of being able to tip the balance. Indeed, it was Most that dictated the course of the post-election negotiations on forming a government as well as the shape of the future cabinet, an unprecedented situation in the 25-year history of free and competitive elections in Croatia. Political scientists agree that new parties seldom form governments, not only owing to their "newness" and thus unpredictability, but also because especially small new groupings often adopt radical positions. However, Florian Grotz and Till Weber's recent research demonstrates that the probability of new parties entering government grows when they succeed in winning over $11 \%$ of parliamentary seats. In such cases, we even find that "the newcomer handicap actually turns into a bonus" (Grotz and Weber, 2016, p. 469).

Additionally, new formations or electoral coalitions - albeit mostly founded by party veterans - won several seats. Milan Bandić and the HDSSB gained two seats each, and Radimir Čačić's Reformists and Ivan Vilibor Sinčić's Human Shield one apiece, with Sinčić becoming the youngest deputy in the Sabor's eighth term. The remaining eight deputies are representatives of national minorities. 
Table 1: Results of the parliamentary election in Croatia, 8th November 2015

\begin{tabular}{|c|c|c|c|c|}
\hline \multirow{2}{*}{ Party } & \multicolumn{2}{|c|}{2015} & Seat change since \\
\cline { 2 - 5 } & Votes & Votes (\%) & Seats & 2011 \\
\hline $\begin{array}{c}\text { Patriotic Coalition (HDZ, HSS, HSP } \\
\text { AS, BUZ, HSLS, Hrast, HDS, ZDS) }\end{array}$ & 746,626 & 33.4 & 56 & 9 \\
\hline $\begin{array}{c}\text { Croatia is Growing (SDP, HNS, } \\
\text { HSU, Croatian Labourist-Labour } \\
\text { Party, A HSS, ZS) }\end{array}$ & 742,909 & 33.2 & 56 & -24 \\
\hline Bridge of Independent Lists & 302,453 & 13.5 & 19 & New \\
\hline $\begin{array}{c}\text { Our Own Right (IDS, RI, PGS) } \\
\text { Milan Bandić 365 - Party of Labour } \\
\text { and Solidarity }\end{array}$ & 42,193 & 1.83 & 3 & $\begin{array}{c}\text { Within the } \\
\text { Kukuriku } \\
\text { coalition }\end{array}$ \\
\hline $\begin{array}{c}\text { Croatian Democratic Alliance of } \\
\text { Slavonia and Baranja (HDSSB) }\end{array}$ & 30,433 & 1.4 & 2 & New \\
\hline Human Shield (Živi zid) & 94,877 & 4.2 & 1 & New \\
\hline $\begin{array}{c}\text { Successful Croatia (Reformists, Go } \\
\text { Ahead Croatia-Progressive Alliance, } \\
\text { Pensioners, ZF, ZDDS) }\end{array}$ & 34,573 & 1.5 & 1 & New \\
\hline ORaH & 38,83 & 1.7 & 0 & New \\
\hline $\begin{array}{c}\text { In the Name of Family - Project } \\
\text { Homeland }\end{array}$ & 23,429 & 1 & 0 & New \\
\hline Others & 66,755 & 3 & 0 & 8 (HL, HSS, HSP \\
AS-HČSP)
\end{tabular}

Source: author's own elaboration based on data published by the State Electoral Commission (DIP). 
Just as important as the winners of the elections were the big losers. These included former Prime Minister Jadranka Kosor, who stood on the list of the Reformists in electoral district V, encompassing the southern part of Slavonia and Syrmia. The list which she headed received only $1.25 \%$ of votes, and she herself only 1673 preferential votes. Former President Ivo Josipović fared even worse - standing in district I, containing part of the capital, he received only 1604 preferential votes, and his list 1.01\%. A further loser was Mirela Holy's ORaH party, which failed to reach the election threshold, despite its good result in the previous year's European Parliament elections. Its leader, in first position on the Zagreb list, received just 5424 preferential votes. Another to fail to win a seat was Željka Markić, leader of the civil group In the Name of Family and initiator of the notorious December 2013 referendum aiming to introduce a ban on single-sex marriages to the constitution (Nikić Čakar and Raos 2014: 69-70). The highest number of preferential votes, on the other hand, went to the leaders of the two main parties: Zoran Milanović $(49,379)$ and Tomislav Karamarko $(42,925)$, who headed their party lists in electoral districts I and IX (northern and part of central Dalmatia) respectively (incidentally, the latter district is seen as an HDZ bastion, and the party secured its best result there, 49,5\%). In general, it was usually the first person on the list who received votes, and it was the HNS that benefited most from the introduction of this possibility, gaining two seats more than was foreseen in the coalition agreement made with the Social Democrats.

\section{FORMATION OF GOVERNMENT AND POST-ELECTORAL CRISIS}

For several days after the election, a deadlock ensued as the main parties quarrelled over who should be deemed the relative winner and be allowed to form a new cabinet. At first, four scenarios were considered: a post-election coalition formed by Most with one of the strongest parties; a coalition in which, owing to the potential for blackmail, the prime minister would come from the ranks of Most (as had occurred in neighbouring Serbia after the parliamentary elections in 2007 and 2012); a minority government formed by the HDZ or SDP, supported by Most; or a so-called grand coalition. Prime Minister Milanović congratulated the members of Most even on the election night, inviting them to work together, while Karamarko followed suit the next day. Most itself sent ambivalent signals, and its activists were divided as to what their next step should be. Party leader Božo Petrov made a notarised statement that Most did not intend to enter a coalition with either of the two main political powers, and if it did he would resign (Lalović, 2015). Yet the arguments the grouping's activists used in 
the debate criticising the idea of forming post-election coalitions demonstrated a profound misunderstanding of the rules of formation and operation of governments in a parliamentary democracy. Stipe Petrina, meanwhile, was trying to force through the idea of a grand coalition. The main objective of this idea was to protect Most from being dominated by the HDZ or SDP. Most called its potential coalition partners "whales", echoing similar concerns expressed by the Liberal Democrats in the United Kingdom at their 1998 party conference. Debating how far they could and should work together with Tony Blair's Labour Party (although in this case no coalition was needed or considered), they feared that too close collaboration would resemble "a mouse in a bed with an elephant (...) the party could lose their identity and independence" (Norris and Evans, 1999 , p. XXII).

Finally, on 17 November talks got under way, to be led by Most simultaneously with representatives of both coalitions. The idea of the negotiations was to agree on positions on the widespread reforms that Most had presented in very general terms. Problematic was the grouping's lack of coherence - it was more of a heterogeneous social movement than an ideologically coherent party - as well as the fact that supervision of the negotiations was entrusted to the National Council (Nacionalno vijeće), a party organ numbering one or two dozen members with no statutory authority. Among the major proposals made by Most before the beginning of talks was decentralisation (including reduction of the number of counties - an idea of which the HDZ was fiercely critical - as well as of other uneconomic units of territorial government, and a change in their organisation), a change in the electoral law and reduction of the number of deputies in the Sabor, a cut in the number of state agencies, monetary reform, and reform to the energy sector, e.g. by construction of several hydroelectric power stations. The course of these discussions was dictated throughout by Most, which firstly added new demands, but also warned partners that it would strictly insist on observance of the designated dates for specific reforms to be introduced, despite failing to declare how it saw its role in the future parliament and government. The end of the first round of negotiations came on 30 November, the date which Most set for both parties to publish their official positions on the proposed reforms. This condition was satisfied, yet the situation remained uncertain. Some Most activists indicated a willingness to support a minority government, although it remained unclear which of the political options they preferred. The future mandatary could also not be decided in spite of two rounds of consultations (26 November and 7 December) which the president held with representatives of the parties that had secured seats in parliament. After unsuccessful attempts at the first sitting of the Sabor (3 December) to choose a leader of the house, 
Most members turned to the idea of a grand coalition (which had been rejected, especially by the SDP, since the announcement of the election results), headed by an independent prime minister or a candidate put forward by Most, and further talks - this time joint - with representatives of the two largest parties. The fact that for the first time both party leaders indeed sat down at the same table can be seen as a certain accomplishment. After several days of talks, however, on 19 December the HDZ leader Tomislav Karamarko rejected the text of the agreement on forming a three-party government, surprisingly signed by SDP leader Zoran Milanović despite the fact that the party board (Glavni odbor) had opposed the establishment of such a coalition (Vuksanović and Špoljar 2015). The matter seemed to be resolved. Yet on 22 December there was a further unexpected twist in the negotiations. Following a visit to the president as part of the third round of negotiations on forming a government, Božo Petrov unexpectedly informed journalists that talks with the Croatia is Growing coalition had come to a definitive end, before accusing Prime Minister Milanović of trying to break up Most and draw a section of the grouping's members towards a centre-left coalition. On 23 December, the HDZ and Most agreed on a candidate for prime minister, the almost completely unknown Croatian Canadian Tihomir Orešković, the financial head of the company Teva Pharmaceutical Industries in Europe who had no power base or political experience. In accordance with her authority, President GrabarKitarović gave him 30 days to form a government. Subsequent negotiations in fact only concerned the composition of the government, often stirring up heated debate between the future coalition partners. Petrov, meanwhile, consistently avoided use of the words "coalition" or "coalition partners", replacing them with the vague and apolitical-sounding concept of "cooperation". This was also the wording in the title of the contract signed by the HDZ and Most, which he used to argue that he had not broken the notarised statement, and despite his position of deputy prime minister in the new coalition government. ${ }^{9}$ Both sides gave assurances that although the candidates for ministers were nominated by the parties, the mandatary had the right to choose from the submitted candidacies, as well as a potential veto. Most demanded a guarantee of control of the ministries essential for its proposed reforms, including justice, administration, agriculture, environmental protection, economy, and above all home affairs. The last of these in particular was the cause of heated dispute, also showing the mutual distrust between the coalition partners. Throughout the negotiations, Most warned that failure to get the home affairs portfolio would mean new elections. Yet while the HDZ and Most argued over the filling of posts and vetoed candidates on several

${ }^{9}$ See Sporazum o suradnji u reformskoj Vladi sklopljen u Zagrebu dana 22. siječnja 2016 g. između Domoljubne koalicije i Most-a nezavisnih lista', http://most-nl.com/sporazum-o-suradnjiu-reformskoj-vladi/ [Accessed January 31, 2016]. 
occasions, even threatening withdrawal from the talks, the future prime minister was actually marginalised throughout the dispute. Ultimately, Orešković's cabinet comprised the prime minister, the two deputy prime ministers, Božo Petrov and Tomislav Karamarko - the latter as the premier's potential replacement - and 20 ministers, 14 of them appointed by the HDZ and six by Most, among whom only a few members of the government have political experience and only three ministers were women. The HDZ nominations of two very controversial figures brought public protest. The first was Mijo Crnoja, appointed as Minister of Veterans' Affairs, and the second Minister of Culture Zlatko Hasanbegović (a controversial right-wing historian, former member of the far-right Croatian Pure Party of Rights and President of the Supervisory Board of the pro-Ustaša Honorary Bleiburg Platoon).

Prime Minister Tihomir Orešković's government statement was presented, and the vote of confidence for the new cabinet made, on 22 January 2016, by law the last permissible date. This was despite the fact that President KitarGrabarovic had forestalled a potential crisis before the vote, scheduled for the late evening, by extending the allotted time by a further 30 days (Article no. 111, The Constitution). Also unusual was the prime minister's address, which was not given as a speech but presented in the form of a multimedia presentation. No doubt at least part of the reason for this was his imperfect command of his mother tongue. The address dealt very much in generalities, largely referring to economic issues. It included references to the need to fight against the crisis, improve the state of public finances, reduce the public debt, accelerate GDP growth, and make better use of European funds. Political issues and those concerning the new cabinet's foreign policy were largely absent. The prime minister referred only - in just one sentence - to the need to carry out consultations regarding the migrant crisis with the neighbouring country governments and the European Commission. It is also notable that whereas in the initial phase of negotiations on forming the new government the future reforms had been the main subject of discussion, with the new government being portrayed as the first government of the true reformers, the presentation contained an empty slide devoted to the specific ministries' objectives (Slide no. 12, The expose).

Following lengthy discussions, the new government was eventually supported by 83 deputies, with 61 against and five abstentions. Votes in favour were given by 56 members of the Patriotic Coalition, 14 from Most, two deputies each from the lists of Mayor of Zagreb Milan Bandić and the HDSSB, Reformists leader Radimir Čačić, Gordana Rusak (who after the elections had first joined the ranks of Drago Prgomet's newly formed Hrid party, before joining the club formed by the HSLS), and four minority representatives. By the time the government was 
appointed, four activists had officially left Most (Drago Prgomet - expelled for secretly meeting with Prime Minister Milanović, Irena Petrijevčanin-Vuksanović, Stipe Petrina, Gordana Rusak), the first two of whom did not take part in the vote; Petrina voted against, leaving only Rusak in favour. Also opposed to the formation of the coalition cabinet was Most economic strategist Ivan Lovrinović (previously considered as a future minister of the economy) ${ }^{10} \mathrm{He}$ claimed that during the negotiations with the HDZ Most had abandoned its reform proposals that had ensured it voter confidence and parliamentary seats, meaning that it would be dishonest to voters to support them.

\section{IMPLICATIONS AND THE 2016 SNAP PARLIAMENTARY ELECTIONS}

The appointment of the new government by no means brought stability, and the coalition remains beset by internal problems. Its first days in power passed in the shadow of rumours spread by the HDZ leader about alleged voter fraud that supposedly cost the party several seats, as well as a scandal connected to the Minister of Veterans' Affairs, Colonel Mijo Crnoja. The source of the conflict was an idea that Crnoja put forward as one of the main aims of his ministry and which was supported by the veterans who have been protesting since November 2013 in a tent outside the entrance to the Ministry of Defence, to publish a list of traitors from the time of the War of Independence. An investigation by journalists revealed that the new minister had been avoiding tax payment for years, declaring fictitious residences (the head of the INA company and one of the directors of Croatian railways had lost their positions for similar misdemeanours). The minister was also found to have unlawfully appropriated funds from a preferential loan and acquired the status of war invalid (Barilar and Penić 2016). For several days, however, the prime minister was unable to make a decision on his future, and even failed to refer to the issue at the first sitting of government. Tomislav Karamarko thought that it was necessary to wait for the situation to become clearer, while Božo Petrov argued that in light of the facts revealed by the media the minister himself should make a decision, but first of all he should abandon the list of traitors idea. In the end, on 28 January, less than a week after his oath, Crnoja resigned. This certainly did not smooth relations between the coalition partners.

From the very beginning, it has looked very likely that this marriage of people of differing views in many fundamental questions will be a short-lived and tempestuous experiment. These differences encompasses both those announced ${ }^{10}$ See Predstavljanje Vlade Republike Hrvatske i glasovanje o povjrerenju Vladi Republike Hrvatske, http://itv.sabor.hr/video/Glasovanje.aspx?ID=7382 [Accessed January 24, 2016). 
in the campaign and negotiations for forming a government, like reform of public finances, debt reduction policy or state decentralisation, and also those consistently omitted, like protection of minority rights, visions of the future workings of the EU, cooperation with other post-Yugoslav states, and solutions to the migration crisis. Asked about its future, former Prime Minister Jadranka Kosor said that "power is a strong glue" (Toma, 2016). But the coalition only lasted six months, constantly riven by internal tensions and the mistrust of partners. The fall of the Orešković government was finally decided by a scandal involving the arbitration proceedings between the Croatian government and the Hungarian fuel company MOL, which had the deciding voice in the matter of the Croatian oil firm INA, despite not having majority shares. The deputy prime minister and HDZ leader wanted to withdraw from this action, yet shortly after this declaration, Nacional weekly revealed that Karamarko's wife worked for MOL lobbyist Josip Petrović, regarded as an éminence grise and an informal member of HDZ personnel. Although formally Ana Karamarko's contract expired before her husband became deputy prime minister, his support for withdrawal from the arbitration process - which was unfavourable to Croatia's interests - caused concerns and resulted in a parliamentary commission opening proceedings against him concerning a possible conflict of interest. In order to deflect attention from personal scandals, the HDZ leader decided to escalate the crisis in the ruling coalition, in June securing the downfall of Timohir Orešković's government, formed together with the HDZ, and claiming that he could form a new cabinet. The motion of no confidence against Orešković was supported by 125 deputies, with 15 against and 2 abstentions. We should remember that Croatia is not short of experience with technocratic prime ministers, but this time the situation was much more complicated. In the 1990s, during the presidency of Franjo Tuđman, who held the position of HDZ leader, only the first two prime ministers were active politicians of the ruling party; the other four were technocrats - although no one had any doubts that the man behind strategy and personnel decisions was Tuđman himself. In Orešković's cabinet, on the one hand, two politicians with little trust for one another wanted to pull the strings. On the other hand, it turned out that the role of figurehead did not quite suit the prime minister. $\mathrm{He}$ demonstrated this by naming as the head of the Security and Intelligence Agency (SOA) a candidate without Karamarko's support, as well as by attempting to prevent him from meddling in the INA affair, and later supporting the Most leader, who demanded that the HDZ leader resign from the position of deputy prime minister. However, although Prime Minister Orešković was aware that he lacked the political back-up to fire Karamarko, he did not have sufficient political instinct to respond to the crisis by dissolving the government himself. 
After the fall of the government, despite his promises Tomislav Karamarko did not succeed in appointing a new cabinet, and President Grabar-Kitarović decided to call snap elections for 11 September 2016. The HDZ then forced Karamarko to vacate the position of party president, for which he was re-elected in April, for the first time following direct elections, in which 92,000 of the 208,000 registered party members voted for him. On 17 July the MEP Andrej Plenković became the HDZ's new leader, garnering the support of 98,000 party members. Plenković's victory led to changes both in the party's internal coalition models and in its ideological profile. The new leader decided that the HDZ should remove its dead weight in the form of radically right-wing coalition partners, in keeping with his vision of a Christian Democratic party with strong roots in European structures.

Some 177 lists were registered in the elections, although both the main actors of the electoral rivalry and the topics of the campaign to a large extent remained unchanged from the previous cycle. Notable, however, was the aforementioned European turn of HDZ, manifested in the party's new leader's continual emphasis on its shared values and affiliation to the European family of Christian democratic parties, as well as the need to strengthen Croatia's position in the European arena and collaborate with other countries in the region (Bolković, 2016). In their election promises, though, the main parties concentrated chiefly on economic matters, including increasing the employment rate and economic growth and raising pay levels. The two main parties' economic programmes were criticised by economists, who viewed them as excessively eclectic and lacking either measures designed to realise the named objectives or timetables for this to happen (Bićanić, 2016, p. 20-22).

At first it seemed that the HDZ, despite the change in leader and rhetoric seeking the support of centrist voters, was in a losing position. A pre-election poll conducted in early August gave an $8 \%$ lead to the left-wing coalition (Graph 1), but the course of the campaign changed on 24 August when the daily newspaper Jutarnji list published tapes with recordings of a meeting between Social Democrat leader Zoran Milanović and representatives of veterans from the so-called Homeland War (Domovinski rat). He used anti-Serb rhetoric, as well as speaking contemptuously of Croatia's other neighbours (Nezirović, 2016). Support for the coalition with the SDP at its helm began to fall after the so-called tapes scandal, and in the elections on 11 September the HDZ was victorious with 61 seats in parliament, defeating the left-wing coalition by 46,000 votes and seven seats (Table 2). The day after the election, Milanović accepted defeat, ruling out the possibility of talks on forming a new government, and also stated that he would not take part in the election of a new head of the DP. As the results 
of parliamentary elections from 2007-2016 show, during Milanović's leadership the party's electorate shrank by 400,000 votes, that is around $40 \%$ in comparison to the 2007 elections. ${ }^{11}$

Table 2: Results of the snap parliamentary election in Croatia, 11th September 2016

\begin{tabular}{|c|c|c|c|c|}
\hline \multirow[b]{2}{*}{ Party } & \multicolumn{3}{|c|}{2015} & \multirow{2}{*}{$\begin{array}{l}\text { Seat change } \\
\text { since } 2011\end{array}$} \\
\hline & Votes & Votes $(\%)$ & Seats & \\
\hline $\begin{array}{l}\text { Patriotic Coalition (HDZ, HSS, HSP } \\
\text { AS, BUZ, HSLS, Hrast, HDS, ZDS) }\end{array}$ & 746,626 & 33.4 & 56 & 9 \\
\hline $\begin{array}{c}\text { Croatia is Growing (SDP, HNS, HSU, } \\
\text { Croatian Labourist-Labour Party, A } \\
\text { HSS, ZS) }\end{array}$ & 742,909 & 33.2 & 56 & -24 \\
\hline Bridge of Independent Lists & 302,453 & 13.5 & 19 & New \\
\hline Our Own Right (IDS, RI, PGS) & 42,193 & 1.83 & 3 & $\begin{array}{l}\text { Within the } \\
\text { Kukuriku } \\
\text { coalition }\end{array}$ \\
\hline $\begin{array}{c}\text { Milan Bandić } 365 \text { - Party of Labour } \\
\text { and Solidarity }\end{array}$ & 74,301 & 3.3 & 2 & New \\
\hline $\begin{array}{l}\text { Croatian Democratic Alliance of } \\
\text { Slavonia and Baranja (HDSSB) }\end{array}$ & 30,433 & 1.4 & 2 & -4 \\
\hline Human Shield (Živi zid) & 94,877 & 4.2 & 1 & New \\
\hline $\begin{array}{c}\text { Successful Croatia (Reformists, Go } \\
\text { Ahead Croatia-Progressive Alliance, } \\
\text { Pensioners, ZF, ZDDS) }\end{array}$ & 34,573 & 1.5 & 1 & New \\
\hline $\mathrm{ORaH}$ & 38,83 & 1.7 & 0 & New \\
\hline $\begin{array}{c}\text { In the Name of Family - Project } \\
\text { Homeland }\end{array}$ & 23,429 & 1 & 0 & New \\
\hline Others & 66,755 & 3 & 0 & $\begin{array}{c}8 \text { (HL, HSS, } \\
\text { HSP AS-HČSP) }\end{array}$ \\
\hline XI district for members of diaspora & - & - & 3 & 3 \\
\hline $\begin{array}{l}\text { XII district - national minority } \\
\text { electoral district }\end{array}$ & - & - & 8 & 8 \\
\hline Total number of seats & & 151 & & 151 \\
\hline
\end{tabular}

$\overline{{ }^{11} \text { See www.izbori.hr }}$ [Accessed November 15, 2016). 


\begin{tabular}{|c|c|c|}
\hline $\begin{array}{c}\text { Total domestic votes (turnout in } 10 \\
\text { electoral districts) }\end{array}$ & $2,238,003(60.82 \%)$ & $\begin{array}{c}2,397,660 \\
(54.3 \%)\end{array}$ \\
\hline Eligible voters & $3,788,788$ & $4,504,251$ \\
\hline Total votes & $2,365,821$ & $2,439,754$ \\
\hline Invalid votes & 39,367 & 42,094 \\
\hline
\end{tabular}

Source: author's own elaboration based on data published by the State Electoral Commission (DIP).

In analysing the election results, we should look at two issues. First, the new HDZ leader's decision not to form a coalition with extreme radical parties showed what the true extent of their strength is, as they are unable to meet the electoral threshold alone. Second, notable is the renewed popularity of Human Shield; in 2015 this grouping barely reached the threshold and gained only one seat, but this time it secured eight, partly at the cost of Most. At the same time, though, the coalition it formed in fact began to collapse immediately after the announcement of the election results, and by the time the new parliament was sworn in Human Shield had only four deputies remaining. Amid an atmosphere of scandal, the party was left by its treasurer, Ivan Đanić, and deputy leader Hrvoje Runtić, who took to social media to publish a declaration about his discovery of financial malpractices among the party leadership. He also claimed that, when he had learned of funds accumulated unlawfully for the election campaign, party leaders (Ivan Vilibor Sinčić, Vladimira Palfi and Ivan Pernar) had forbidden him to mention it and tried to bribe him, arguing that this was unimportant and that a stable third power was necessary on the Croatian political scene (Nacional, 2016, Godeč, 2016).

The process of forming a government ran much more smoothly this time. This was undoubtedly helped by the shrewdness of Andrej Plenković, who showed the permanently hesitant Most leader that in theory the HDZ could form a cabinet without his party. In the end, the coalition was maintained, with 15 ministers from the HDZ in the new government. However, in choosing candidates for the HDZ's ministerial quota, Plenković decided against working with the previous members of the government associated with the party's radical right wing (particularly culture minister Zlatko Hasanbegović, who faced considerable opposition from society and the academic community) as well as four from Most. The junior coalition partner succeeded in retaining the minister of foreign affairs' portfolio, which had been a bone of contention when the previous cabinet had been formed. Yet Plenković did not agree to Most providing the minister of economy, maintaining that the main coalition party should be responsible for fulfilling its economic promises. He made a major concession to the coalition 
partner in agreeing to the Most leader Božo Petrov, who had decided not to enter the government on this occasion, being Speaker of the Sabor for half of its term, although it is usually the strongest party which fills this position. In a vote on 19 October, Andrej Plenković's government was supported by 91 deputies, three abstained, and 45 voted against. Cooperation between the two parties is working better than in the previous cabinet, although certain discrepancies soon appeared between the partners, such as regarding the law pushed through by Most - and not supported by the HDZ - on pay reductions to public officials. This time, however, the HDZ's position in the government is considerably stronger than after the previous elections, and the new prime minister has already reminded his coalition partner that apart from them the government is also supported by minority deputies and representatives of several small groupings, which evidently reduces Most's potential for blackmail. While for the time being the tensions between the coalition partners seem smaller, it may well be that power is not a strong enough glue for the government to last the whole term in its current form.

\section{CONCLUSION}

In general, the hitherto stable Croatian party system seems to show signs of having entered a period of political instability - a situation, incidentally, which can also be discerned elsewhere in the region. The reasons for Most's electoral success (as well as the relatively good result of another new party, Human Shield, in the 2016 snap elections), in keeping with Tavits's advice (Tavits, 2007, p. 115), should be sought above all in voters' growing disappointment with the two main groupings - the centre-right HDZ and centre-left SDP - as well as the low level of trust towards political institutions, and particularly parties. Furthermore, the new parties have been aided by a complicated and tempestuous, and partially also unpredictable economic situation (the country's low credit rating, problems of people who took out mortgages in Swiss francs, and more broadly the Eurozone crisis), but also the international situation (e.g. the crises within the EU and the migrant crisis). Media reports on these events also had a part to play, potentially giving voters the impression that the old parties were not flexible enough to respond to these challenges and propose appropriate solutions. It is therefore hardly surprising that in both sides of Europe there is an increasing emergence of new groupings, often difficult to classify in ideological terms, questioning the status quo with anti-establishment and sometimes even anti-system rhetoric. Furthermore, these groupings often paint themselves as anti-political and set themselves apart from the established parties through their ephemeral organisational structure - and often lack of it. In 
the long run, however, this weakens their chances of surviving in the political arena (Beyens, Lucardie and Deschouwer, 2016). In this case, therefore, Croatia takes its place in a broader trend of political contestation visible in both parts of Europe. Besides this main picture of the situation, our analysis of the elections also leads to several conclusions that are more detailed but similarly worthy of attention.

Firstly, the appearance on the party scene of new, strong players changed the previous coalition models, as shown by the fact that the government formed after the 2015 election was co-created by a new grouping - or rather a loose coalition of local politicians - Most. Despite this, the results obtained by the HDZ and SDP in the two last election cycles demonstrate that, contrary to the opinions of commentators, Most did not so much take seats away from the two main parties as gain votes from people who had previously voted for parties unable to reach the election threshold. Between 2010 and 2015, on average the two main parties secured $67 \%$ of seats (Raos, 2015, p. 9). In the last elections, on the other hand, they controlled some $76 \%$ of the Sabor. According to some political scientists, "governing is a risky business" (Deschouwer, 2008, p. 12), and a new party entering government has a weakened position in polls and - especially for small groupings - may be exposed to "electoral risk" (Deschouwer, 2008, p. 15). In this case, however, it is interesting to note that Most maintained its parliamentary status and coalition potential. The ruling coalition of which it was part was renewed after the 2016 elections. This was in spite of the fact that the coalition partners were by no means close ideologically or their previous collaboration a great success. And yet good coalition experience is often seen as advantageous in subsequent negotiations on forming a government (Martin and Vanberg, 2007, p 182). Furthermore, Most activists, with their frequent changes of opinion, seemed already to have squandered their political capital, and after the fall of the Orešković government Božo Petrov once again categorically ruled out the prospect of Most forming a coalition with either of the two main parties, as both had deceived them (Petrov, 2006). As we see, these declarations (again) did not stand the test of time.

Secondly, the parliament that emerged after the election was extremely fragmented. This was caused by the formation of broad pre-election coalitions, but also by subsequent non-electoral parliamentarisation, meaning that parties which had not participated in the election gained seats as they emerged after party splits (Most alone had four deputies leave before appointment of Oreškovic's government). After the 2015 elections, there were as many as 18 groupings in the Sabor (by the end of the term this figure had risen to 21), seven of them with just one or two seats apiece. The effective number of parliamentary 
parties was 4.78 , whereas after the two previous election cycles it has been 3.82 (2011) and 3.07 (2007) (Raos, 2015, p. 8). Parliament therefore appears to be becoming increasingly fragmented. Given the fact that there are again 17 parties represented in parliament following the 2016 elections, we can speak of symptoms of deconsolidation of the party system.

Thirdly, despite the changes in format (number of relevant parties) and mechanisms of the party system (coalition models), the main axes of sociopolitical conflicts remain largely unchanged. Political disputes continue to be dominated by the centre-peripheries dimension (Zagreb versus the rest of the country - also the source of the regular calls for decentralisation of the state) and conflict over historical identity issues (Kasapović, 2016). In fact, before almost every election a topic resurfaces that many voters see as irrelevant in the face of the country's economic problems: the divisions of society, daring back to the Second World War, into descendants of the Partisans and the Ustaše (Kasapović, 2016). The band TBF were among those to voice society's weariness with this subject in the lyrics of one of their well-known songs, Smak svita: "In the Sabor this morning again the same nonsense, whose father was an Ustaša and whose a Partisan".

Fourthly, there are no visible symptoms of an improvement in the way the political scene works, even if a kind of "moral renewal" of parties was one of the slogans of the parties competing to be the third power, including Human Shield and Most. The results of the "Barometer of Croatian Society" cyclical research conducted by the Ivo Pilar Institute show that trust in political parties grew on a 10-point scale, with 10 being the best result, from 2.05 points in 2015 to 2.49 in 2016. The Sabor's result was little better, at 2.52 and 2.86 respectively. ${ }^{12}$ It is therefore difficult to speak of society discerning a diametric improvement after the new parties took their parliamentary seats.

Lastly, but no less importantly, it would appear that the reasons for the new parties' success, paradoxically, should not be sought in the fact that Croatia is a young and not fully consolidated democracy (as shown by indicators from research by the Freedom House foundation),${ }^{13}$ especially as to date the Croatian party system had been stable compared to other CEE states. Rather, the causes lie in the phenomenon noted by Margit Tavits, that "more voters are likely to support a newcomer when democracies have endured longer and when most existing parties have already rotated through a cabinet status" (Tavits, 2007, p. 133). According to her, there may be fewer new parties in such circumstances,

\footnotetext{
${ }^{12}$ See Pilarov barometar hrvatskoga društva (2015., 2016.), Zagreb: Institut društvenih znanosti Ivo Pilar, http://barometar.pilar.hr [Accessed November 15, 2016).

13 See Croatia, Nations in Transit 2016 https://freedomhouse.org/report/nations-transit/2016/ croatia [Accessed November 15, 2016).
} 
but at the same time they have greater chances of electoral success - as the Croatian case clearly demonstrates. It therefore seems likely that even if Most loses its election fortune, this will leave a sizeable space in which the next new party can manoeuvre.

\section{REFERENCES}

BARILAR S., and PENIĆ, G., 2016. Greškom ministar, dossier Crnoja. Jutarnji list, 27 January 2016, Available at: http://www.jutarnji.hr/dossier-crnojalazno-prebivaliste--utaja-poreza--fizicki-sukobi--zatvor--sporni-kredit---a-ratni-invalid-nije-jer-je-bio-ranjen--nego-zbog-bolesti-mozga/1507778/ [Accessed January 27, 2016].

BIĆANIĆ, I., 2016. 4 razloga zašto programi HDZ-a i SDP-a ništa ne valjaju, Globus no. 1342, August 26.

BOLKOVIĆ, R., 2016. Intervju Andrej Plenković, Globus no. 1341, September 19.

BEYENS, S., LUCARDIE, P., and DESCHOUWER, K., 2016, The life and death of new political parties in the low countries, West European Politics 39(2), pp. 257-277.

The Constitution of the Republic of Croatia (consolidated text), [online] Available at http://www.sabor.hr/Default.aspx?art=2409 [Accessed January 31, 2016].

The expose. 2015, Prihvatimo izazove. Strategija transformacije Hrvatske, [online] Available at http://www.sabor.hr/predstavljanje-vlade-rh-2016 [Accessed January 24, 2016].

DESCHOUWER, K., 2008. Comparing newly governing parties. IN: K. DESCHOUWER, eds. New parties in Government. In power for the first time edited, New York: Routledge, pp. 1-16.

GROTZ, F., and WEBER, T., 2016, New parties, information uncertainity, and government formation: evidence from Central and Eastern Europe, European Political Science Review 8(3), pp. 449-472.

GODEČ, Ž., 2016. Svjedočanstvo radnika koji šefici Živog zida bili jamci za kredit, Globus no. 1348, October 7.

GONG, 2014. Novo izborno zakonodavstvo 2014. Analize i preporuke Gong-a, (Zagreb: GONG).

HARMEL, R. \& ROBERTSON, J. D., 1985, Formation and success of new parties. A cross-national analysis, International Political Science Review 6(4), pp. 501-523.

HUDELIST, D., 2015. Mi smo Most prema HDZ-u i SDP-u: Insajderski izvještaj iz vodeće snage treće opcije, Globus, October 16. 
Jutarnji list, (2016). Intervju za Magazin, Smiljana Leinert Novosel: Žene su dosljedni birači. Muškarci često mijenjaju mišljenje, Jutarnji list, January 17, [online] Available at http://www.jutarnji.hr/zene-su-dosljedniji-biraci-muskarci-cesto-mijenjaju-misljenje/1499388/ [Accessed January 23, 2016].

KASAPOVIĆ, M., 2016. Velika je zabluda da HDZ i SDP gube birače, Globus, September 16.

KASAPOVIĆ, M., 2011. Drugi kritični izbori u Hrvatskoj - slom jednog modela vladanja, Političke analize, no. 8, pp. 3-9.

KASAPOVIĆ, M., 2001. Demokratska konsolidacija i izborna politika u Hrvatskoj 1990-2000., In: M. KASAPOVIĆ, eds. Hrvatska politika 19902000. Izbori, stranke i parlament u Hrvatskoj. Zagreb: FPZ.

KEY, V. O., 1955. A Theory of Critical Elections, The Journal of Politics, 17(1), pp. 3-18.

LALOVIĆ, D., 2015. Postizborni igrokaz i umijeće nemogućeg, [online] Available at http://politickamisao.com/postizborni-igrokaz-i-umijecemogucega/ [accessed December 17, 2015].

LARGO, I. and MARTINEZ, F., 2011. Why New Parties?, Party Politics, 17(1), pp. 3-20.

LUCARDIE, P., 2000. Prophets, Purifiers and Prolocutors. Toward a Theory on the Emergence of New Parties, Party Politics, 6(2), pp. 175-185.

LOVRIĆ, J., 2015. Hrvatska izabrala prvu predsjednicu u povijesti, Jutarnji list,January 12, [online] Available at http://www.jutarnji.hr/kolindi-jenajvise-pomogao-hdz--ali-i-sdp-ova-vlada/1272176/ [Accessed January 12, 2015].

LOVRINOVIĆ, I., 2015. Ni SDP-u ni HDZ-u nije palo na pamet promijeniti ekonomsku filozofiju, Nacional, October 20.

MARTIN, L. W., and VANBERG, G., 2007. Coalition theory and government formation, in C. BOIX and S. C. STONES, eds., The Oxford handbook of political science. Oxford: Oxford University Press.

MIKUCKA-WÓJTOWICZ, D., 2016. Resilient or Resistant? The Impact of Transnational Party Cooperation on Croatian Political Parties, East European Politics, 32(2), pp. 236-257.

Nacional 2016. Hrvoje Runtić iz Živog zida teško optužio stranačko vodstvo, [online] Available at http://www.nacional.hr/hrvoje-runtic-iz-zivog-zidatesko-optuzio-stranacko-vodstvo [Accesed September 19, 2016].

NIKIĆ ČAKAR, D. and RAOS, V., 2014. Croatia, European Journal of Political Research Political Data Yearbook, 53, pp. 66-77.

NIKIĆ ČAKAR, D. and ČULAR, G., 2016. Organisational Structures of Political Parties in Croatia, in. K. SOBOLEWSKA-MYŚLIK, B. KOSOWSKA- 
GĄSTOŁ, P. BOROWIEC, eds., Organisational Structures of Political Parties in Central and Eastern European Countries. Krakow: Jagiellonian University Press.

NEZIROVIĆ, V., 2016. Sastanak u središnjici SDP-a," Jutarnji list, August 24, [online] Available at http://www.jutarnji.hr/vijesti/hrvatska/ ekskluzivno-jutarnji-u-posjedu-tajne-snimke-sa-sastanka-milanovica-ibranitelja/4640180/ [Accessed November 20, 2016].

NORRIS, P. and EVANS, G., 1999. Introduction: Understanding Electoral Change," in G. EVANS and P. NORRIS, eds., Critical Elections. British Parties and Voters in Long-term Perspectives, London-Thousand Oaks-New Delhi: Sage.

Pilarov barometar hrvatskoga društva (2015., 2016.), [online] Avilable athttp:// barometar.pilar.hr. Zagreb: Institut društvenih znanosti Ivo Pilar [Accessed November 15, 2016].

PETROV B., 2016., Neka oni sanjaju o preslagivanjima a mi idemo na izbore," Jutarnji list June 16, [online] Available at http://www.jutarnji.hr/vijesti/ hrvatska/petrov-neka-oni-sanjaju-o-preslagivanjima-mi-idemo-na-izboreali-treba-se-dogovoriti-kada/4445334/ [Accessed November 11, 2016].

RAOS, V., 2015, Izbori 2015.: jesmo li ušli u razdoblje nestabilnosti i nepreglednosti?, Političke analize, 24, pp. 3-11.

SIKK, A., 2011. Newness as a winning formula for new political parties, Party Politics, 18(4), pp. 465-486.

SIKK, A., 2005. How unstable? Volatility and the genuinely new parties in Eastern Europe, European Journal of Political Research, 44, pp. 391-412.

Sporazum. 2016. Sporazum o suradnji u reformskoj Vladi sklopljen u Zagrebu dana 22. siječnja 2016 g. između Domoljubne koalicije i Most-a nezavisnih lista, Available at http://most-nl.com/sporazum-o-suradnji-u-reformskojvladi/ [Accessed January 31, 2016].

ŠONJE,V., 2014. Mijenjati se ili nestati: tri godine vlade Zorana Milanovića iz ekonomskog ugla, Političke analize, 20, pp. 3-14.

TAGIROV, T., 2015. Hrvatska - Parlamentarni izbori: Poraz velikih partija, Vreme, November 12, [online] Available at http://www.vreme.com/cms/view. php?id=1341751 [Accessed November 25, 2015].

TAVITS, M., 2007. Party System in the Making: The Emergences and Success of New Parties in New Democracies, British Journal of Political Science, 38, pp. 113-133.

TAVITS, M., 2006. Party System Change, Party Politics, 12(1), pp. 99-119.

TOMA, I., 2016. Premijer bez autoriteta? Kriza otkriva tko doista ima moć u vladi, Jutarnji list, January 29, [online] Available at http://www.jutarnji.hr/ 
premijer-bez-autoriteta--kriza-otkriva-tko-doista-ima-moc-u-vladi/1509210/ [Accessed January 29, 2016).

Večernji list. 2015. Ima li HDZ razloga za brigu? Koliko će SDP profitirati forsiranjem domoljublja u kampaniji?, Večernji list, September 27, [online] Available at http://barometar.vecernji.hr/topics/slug/ima-li-hdz-razloga-zabrigu-koliko-sdp-moze-profit/ [Accessed January 23, 2016].

VUKSANOVIĆ, A. and ŠPOLJAR, M., 2015. S ovakivim HDZ-om kakav je danas SDP ne može surađivati u nekoj tripartnoj vladi, Večernji list, December 12, [online] Available at http://www.vecernji.hr/izbori2015/glavni-odborsdp-a-o-tijeku-pregovora-1044403 [Accessed December 12, 2015].

Zakon o izborima zastupnika u Hrvatski Sabor, Narodne novine 2015, no. 19.

ZAKOŠEK, N., 2002. Politički sustav Hrvatske, Zagreb: FPZ. 